\title{
Measurement of Diffusion Profile of Boron in a Iron by Secondary-ion Mass Spectrometry and Determination of Its Diffusion Coefficient
}

\author{
Keisuke Hamana ${ }^{1)}$, Ryusuke NaKamura ${ }^{1)^{*}}$, Hiroshi Numakura ${ }^{1)}$ and Takeyuki Suzuki ${ }^{2)}$ \\ 1) Department of Materials Science, Graduate School of Engineering, Osaka Prefecture University \\ 2) The Institute of Scientific and Industrial Research, Osaka University
}

Abstract: We report an attempt to determine the diffusion coefficient of B in $\alpha$ Iron by measuring the penetration profile by means of secondary-ion mass spectrometry (SIMS). Pure iron plates of grain-size of 1 to $3 \mathrm{~mm}$ were prepared, and thin films of Fe-B alloy $(200 \mathrm{~nm})$ and alumina $(50 \mathrm{~nm})$ were deposited on the surface as a $\mathrm{B}$ source and a capping layer, respectively. The samples were subjected to diffusion annealing at $700^{\circ} \mathrm{C}, 800^{\circ} \mathrm{C}$, and $900^{\circ} \mathrm{C}$ for certain periods of time, and the intensity of secondary ions of B was measured as a function of depth by SIMS. The mesa method was employed, in which a groove is prepared first around the target area by sputtering, and then the depth profile of B through the inner pillar was obtained. The concentration profiles thus obtained were analysed with the thin-film solution, the error-function solution, and also using Hall's method, depending on the form of the profile. The diffusion coefficient was of the order of $10^{-18} \mathrm{~m}^{2} \mathrm{~s}^{-1}$ in all the cases, which is seven to eight orders of magnitude smaller than those evaluated from deboronising experiments in the $1950 \mathrm{~s}$, but is close to recent theoretical prediction for substitutional diffusion.

Keywords: boron; diffusion; $\alpha$ Iron; secondary-ion mass spectrometry.

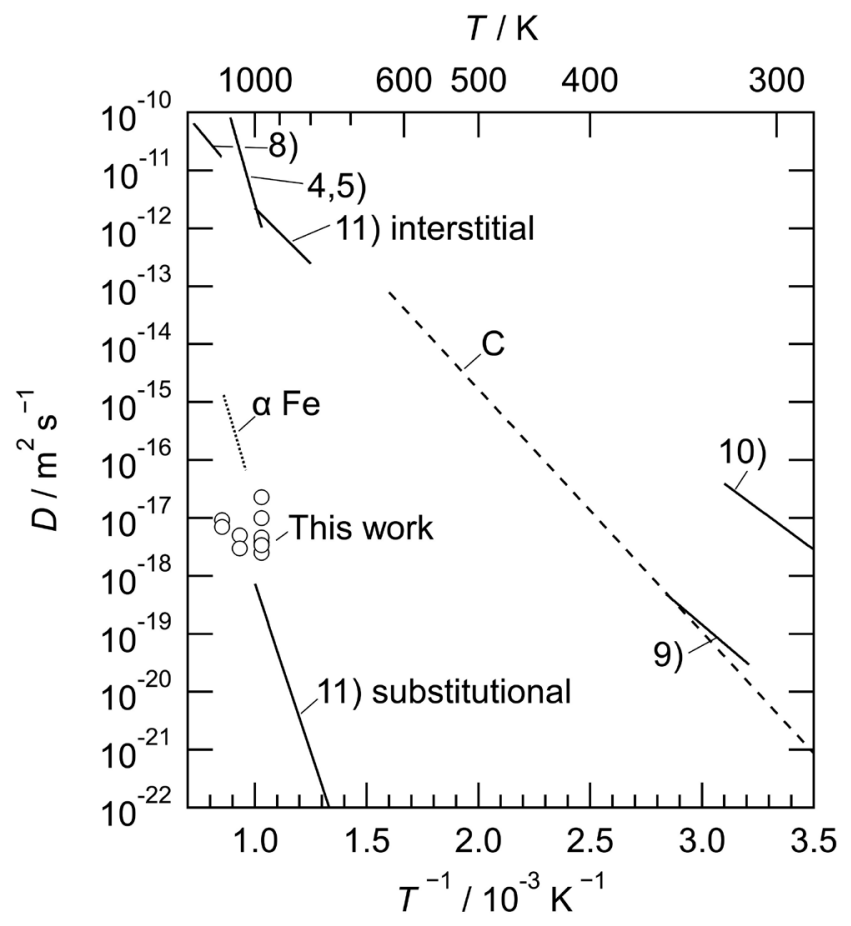

Received on Oct. 18, 2019 ; Accepted on Jan. 9, 2020

* Corresponding author. E-mail : nakamura@mtr.osakafu-u.ac.jp, Address : Osaka Prefecture University, 1-1 Gakuen-cho Naka-ku Sakai Osaka 599-8531 


\title{
二次イオン質量分析法による $a$ 鉄中のホウ素の拡散浸透 プロファイルの測定と拡散係数の決定
}

\author{
濱名 桂佑 $^{1)} \cdot$ 仲村 龍介 $^{1) *}$ *沼倉 宏 $^{1)} \cdot$ 鈴木 健之 ${ }^{2)}$
}

Measurement of Diffusion Profile of Boron in $\alpha$ Iron by Secondary-ion Mass Spectrometry and Determination of Its Diffusion Coefficient

Keisuke Hamana, Ryusuke Nakamura, Hiroshi Numakura and Takeyuki SuzuKı

\section{1. 緒言}

ホウ素 (B) は数ppm程度の微量な添加によって鉄鋼の 焼入れ性を向上させる効果をもつ。これはBが $\gamma$ 相の粒界 に偏析することにより粒界が安定化し，冷却過程におい て $\alpha$ 相への変態を抑制するためと理解されている ${ }^{1,2)} 。 一$ 方 で，熱処理の過程で余剩のBが化合物を形成すると逆に焼 入れ性を低下させる。熱処理によってミク口組織および機 械的特性を適切に制御するには，Bの固溶度や拡散係数の 信頼できるデータが必要である。しかし，Bの固溶度は $\alpha$ 鉄中では 20 mass ppm (100 at.ppm), $\gamma$ 鉄中では 40 mass ppm (200 at. ppm) 程度 ${ }^{3)}$ と極めて低いゆえに, 種々の実験に必 要な希薄固溶体試料の準備や濃度の分析が難しい。そのた め，固溶形態は未だに明らかでなく，信頼できる拡散係数 の值も得られていない。

鉄中のBの拡散係数は，1950年代に最初の報告がなされ た。Busby ら ${ }^{4,5)}$ は，均一な濃度の Fe-B合金の表面から B が 脱離する際の表面近傍の濃度分布を測定する長距離拡散 の実験により拡散係数を求めた。Fig.1にその温度依存性 を， $\alpha$ 鉄の自己拡散係数 ${ }^{6}$ (点線) および $\alpha$ 鉄中の炭素 $(\mathrm{C})$ の拡散係数 ${ }^{7)}$ (破線) とともに示す。得られたBの拡散係 数は $\mathrm{C}$ の拡散係数の高温への外挿值と近く，侵入型による 拡散機構が示唆された。しかし，拡散の活性化エネルギー $(2.68 \mathrm{eV})$ が鉄中のCの拡散 $(0.83 \mathrm{eV})$ より著しく大きく, 鉄の自己拡散 $(2.60 \mathrm{eV})$ に近い。この点は理解し難い。後 続のWang $5^{8)}$ も同様の長距離拡散実験を行った。罒中の データは Fe-3 mass\% $\%$ Si固溶体合金における Bの拡散係数 である。彼らの測定值はCの拡散係数と近いが, Busby ら が得た值とは大きく食い違う。また, Thomas and Leak ${ }^{9)}$ と Hayashi and Sugeno $^{10)}$ は, 力学損失 (スヌーク緩和) の実験 により原子のジャンプ頻度を測定し拡散係数を決定した。
両者が得た Bの拡散係数は 3 桁程度の差がある。最近の Fors and Wahnström ${ }^{11)}$ による理論計算では, B は鉄中で侵入 型八面体位置と置換型位置の両方を占有する可能性が示さ れ，各々の場合の拡散係数が計算された。侵入型機構の拡 散係数はBusbyらやWang らの実験值と近く，活性化工ネ ルギーはCと同程度である。一方, 置換型機構の拡散係数 は鉄の自己拡散係数よりも小さい。

以上の報告を概観すると, Thomas and Leakの実験は測定 精度に, Hayashi and Sugenoの実験は再現性に疑問が残る。 それぞれCを 90 at. ppm および70 at. ppm含む試料で測定が

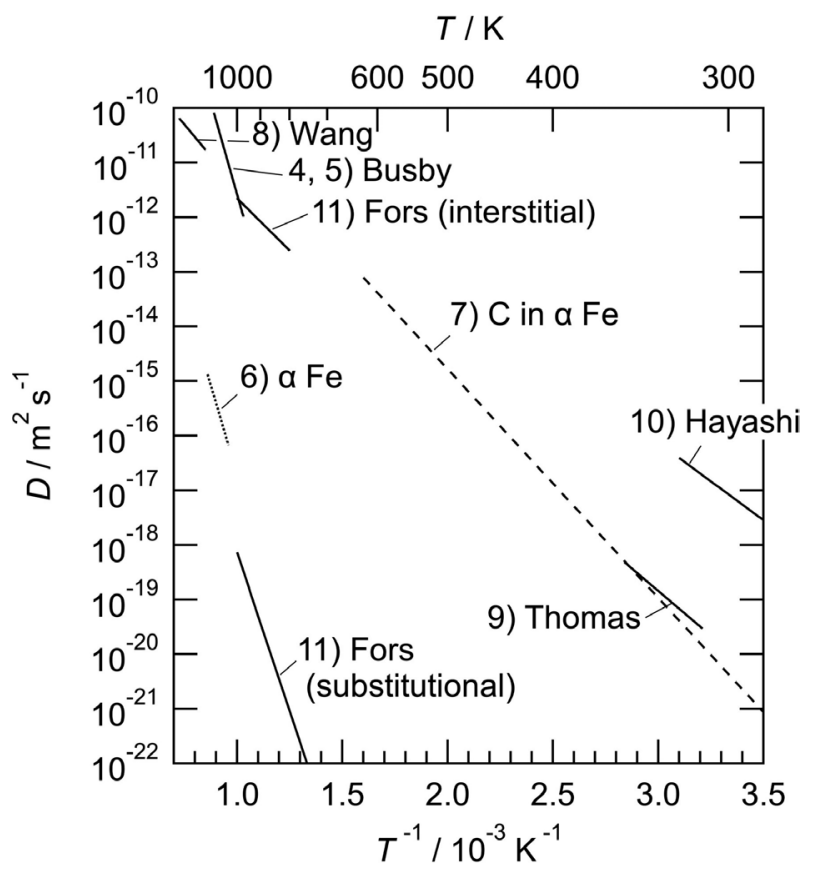

Fig. 1. Reported data of the diffusion coefficient of $\mathrm{B}$ in $\alpha$ Iron. Dotted and dashed lines indicate the self-diffusion coefficient of iron and the diffusion coefficient of $\mathrm{C}$ in $\alpha$ Iron, respectively.

2019年10月18日受付２020年1月9日受理（Received on Oct. 18, 2019; Accepted on Jan. 9, 2020)

1) 大阪府立大学大学院工学研究科マテリアル工学分野 (Department of Materials Science, Graduate School of Engineering, Osaka Prefecture University)

2）大阪大学産業科学研究所 (The Institute of Scientific and Industrial Research, Osaka University)

* Corresponding author. E-mail : nakamura@mtr.osakafu-u.ac.jp, Address : Osaka Prefecture University, 1-1 Gakuen-cho Naka-ku Sakai Osaka 599-8531 
行われており，その寄与も懸念される。BusbyらとWang ら の実験データが食い違う理由は, 不純物の種類や濃度, 試 料に含まれる $\mathrm{B}$ の濃度が固溶限を超えること，扎よび分析 手法の精度などの種々の要因が考えられる。また, 脱離現 象は, 固体中の拡散と表面からの脱離の二つの過程で進行 する。前者が律速となるような条件が維持されなければな らないが，その点は明らかではない。そこで本研究では， 純鉄の表面にFe-B 合金薄膜を堆積して拡散熱処理を施し, $\mathrm{Fe}$ 中へのBの拡散浸透プロファイルから Bの拡散係数の 決定を試みた。濃度プロファイルの測定には，ppmレベル の検出感度があるSIMSを用いた。Fe と同じく Bの固溶度 が低い $\mathrm{Ni}_{3} \mathrm{Al}^{12)}$ や $\mathrm{TiAl}^{13)}$ において, 二次イオン質量分析器 （SIMS）を用いてBの拡散プロファイルを計測した例があ る。

\section{2. 実験方法}

\section{$2 \cdot 1$ 試料作製}

電解鉄（純度 $99.99 \%$ 以上）をアーク溶解してボタンイン ゴットを作製した。これを冷間圧延して厚さ $1 \mathrm{~mm}$ の板と し, 圧延板から寸法 $10 \mathrm{~mm} \times 50 \mathrm{~mm}$ の長方形の板を切り出 した。その後, $850^{\circ} \mathrm{C} て ゙ 3 \mathrm{~h}$ 真空焼鈍し，圧延により生じた ひずみを除去した。続いて，ひずみエネルギーを駆動力と する異常粒成長を利用したひずみ焼鈍法 ${ }^{14,15)}$ により，結晶 粒を粗大化させた。引張試験機を用いて，上記の板状試料 を室温で $5.3 \%$ 塑性変形させた。これを縦型電気炉の上部 から, $850^{\circ} \mathrm{C}$ に保持した中心部に向かって速度 $10.8 \mathrm{~mm} \mathrm{~h}^{-1}$ で降下させた。その結果, 結晶粒径はもとの $100 \mu \mathrm{m}$ から 1 〜 $3 \mathrm{~mm}$ に粗大化した。これから $4 \mathrm{~mm} \times 5 \mathrm{~mm} \times 1 \mathrm{~mm}$ の試 片を切り出し，表面を鏡面状に仕上げた。

真空蒸着装置を用いて，鏡面研磨した純鉄試料表面に $\mathrm{Fe}-\mathrm{B}$ 合金薄膜を蒸着した。純鉄と純ホウ素をアーク溶解 して Fe-17 at.\%B合金を作製し，粒状にしたものを蒸着源 とした。合金薄膜の膜厚は 50〜200 nm とした。この薄膜の 濃度を ICP 発光分光分析した結果，Bの濃度は 0.13 mass\% (0.65 at.\%) であった。

試料を透明石英菅に真空封入し, $700 \sim 900^{\circ} \mathrm{C}$ の温度域で 所定の時間，拡散熱処理を行った。熱処理を施した一部の 試料の濃度分布をSIMS で測定したところ, Bが純鉄内部 へ拡散侵入せずに，脱離することが明らかになった。これ を防ぐために, Fe-B合金薄膜の上に高周波スパッタリング 法で $50 \mathrm{~nm}$ の厚さの $\mathrm{Al}_{2} \mathrm{O}_{3}$ 薄膜を堆積させることにした。

$\mathrm{Fe} / \mathrm{Fe}-\mathrm{B}(50 \sim 200 \mathrm{~nm}) / \mathrm{Al}_{2} \mathrm{O}_{3}(50 \mathrm{~nm})$ と構成される試料 を $700{ }^{\circ} \mathrm{C}$ で $2.75 \mathrm{~h}, 5.5 \mathrm{~h}$ および $11 \mathrm{~h}, 800{ }^{\circ} \mathrm{C} て ゙ 2.75 \mathrm{~h}$ および $5 \mathrm{~h}, 900^{\circ} \mathrm{C}$ で $0.75 \mathrm{~h}$ および $1.5 \mathrm{~h}$ の条件で拡散熱処理した。 以後, 熱処理条件を $700^{\circ} \mathrm{C} \times 2.75 \mathrm{~h}$ などと表す。

\section{$2 \cdot 2$ 濃度プロファイルの測定}

四重極型の二次イオン質量分析器ATOMICA SIMS 4100
を用いて深さ方向のBの濃度分布を分析した。測定領域 を $300 \mu \mathrm{m} \times 300 \mu \mathrm{m}$ とし，一次イオンビームには $\mathrm{O}^{2+}$ を用い $9 \mathrm{keV}$ で入射させた。 ${ }^{11} \mathrm{~B}$ と ${ }^{10} \mathrm{~B},{ }^{56} \mathrm{Fe}$ 扎よび保護膜の成分で ある ${ }^{27} \mathrm{~A} 1$ のイオン強度 (一秒あたりのカウント数) を同時 に計測した。触針式表面段差計Dektak 150を用いて分析領 域のスパッタクレータの深さを測定し, 測定で得られた強 度一時間のプロファイルを強度一距離のプロファイルに変 換した。

Fig.2 に熱処理前の試料における B の強度分布を示す。B の強度は ${ }^{11} \mathrm{~B}$ と ${ }^{10} \mathrm{~B}$ の強度の合計である。この試料の Fe-B 薄 膜の膜厚は約 $50 \mathrm{~nm}$ であり, $\mathrm{Al}_{2} \mathrm{O}_{3}$ は堆積していない。得ら れたプロファイル (\#1) は, 期待されるプロファイル（実 線）と比べて，およそ50 $\mathrm{nm}$ の界面付近での濃度の減衰は 鈍く, 試料内部の強度レベルが高い。単純に表面から深さ 方向にスパッタしてゆくと, クレータの開口部が次第に広 くなってゆく。そのため, 側壁に傾斜が生じる。その場合 の試料縦断面を Fig.2の模式図\#1に示す。このとき，表面 に近い部分から Bがスパッタされることになる。このよう なクレータ側壁からの余分な Bが検出されるのを抑えるた めに, SIMSに扎いてメサ法 ${ }^{16,17)}$ として知られている方法 を適用した。メサ法では，まず測定したい領域の周囲をス パッタして溝を掘削する。そして，模式図\#2のように残つ
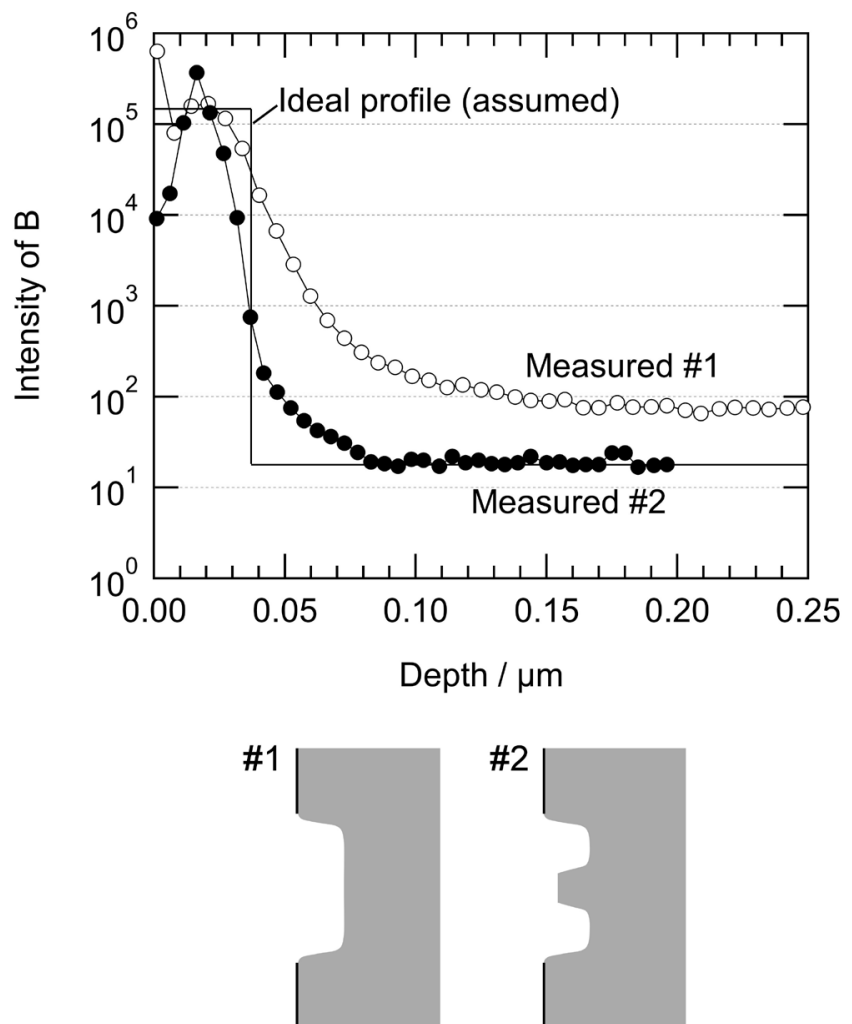

Fig. 2. Depth profiles of the intensity of secondary ions of B in $\alpha$ Iron before diffusion-annealing measured by SIMS. \#1: simple crater, \#2: the mesa method. Lower illustrations show the shape of the crater formed by simple sputtering, $\# 1$, and by the mesa method, \#2. 
た内側の突起部分をスパッタし，深さ方向に分析する。メ サ法で測定した結果がプロファイル \#2である。プロファイ ル \#1 に比べて界面付近の濃度の減衰は鋭く, 鉄内部の強度 レベル，すなわちバックグラウンドレベルが低下し，期待 されるプロファイル (実線) に近づいた。この結果にもと づいて，メサの外堀部分 (outer) と本測定部分（inner）の寸 法をそれぞれ300 $\mu \mathrm{m} \times 300 \mu \mathrm{m}$ および $100 \mu \mathrm{m} \times 100 \mu \mathrm{m}$ とし て，拡散熱処理した試料の分析を行った。

\section{3. 実験結果}

\section{$3 \cdot 1$ 濃度と二次イオン強度の関係}

$\mathrm{B}$ 濃度 $c_{\mathrm{B}}$ が既知の試料における $\mathrm{B}$ の二次イオン強度 $I_{\mathrm{B}}$ を 測定した。その関係をFig.3に示す。点a 扎よびbは，アメ リ力国立標準技術研究所 (NIST) から入手した低炭素鋼の 標準試料 (1761a および1763a)，点 c およびdは純鉄と純B をアーク溶解して作製し ICP分析を行った合金，および点 e はFe-B蒸着膜に打ける B の強度である。NISTの標準試料 には主な合金元素として C, Si， Cr およびMnなどが 0.2 2.0 mass\%含まれる。Bの含有量は 23 および 54 mass ppmで ある。cとdのB濃度は 180 および 824 mass ppm，eのB濃度 は2・1で述べたように 1300 mass ppm (0.13 mass\%) である。 いずれも， $\alpha$ 鉄と $\mathrm{Fe}_{2} \mathrm{~B}$ の二相分離の状態にあると考えられ るので, 試料の複数の領域で $300 \mu \mathrm{m} \times 300 \mu \mathrm{m}$ の範囲から 強度を取得し，その平均值をデータ点とした。強度の䛊差 棒は数個所の平均值の標準偏差を示す。点 $\mathrm{a}$ の測定領域 が一つに限られるため, 䛊差棒はない。

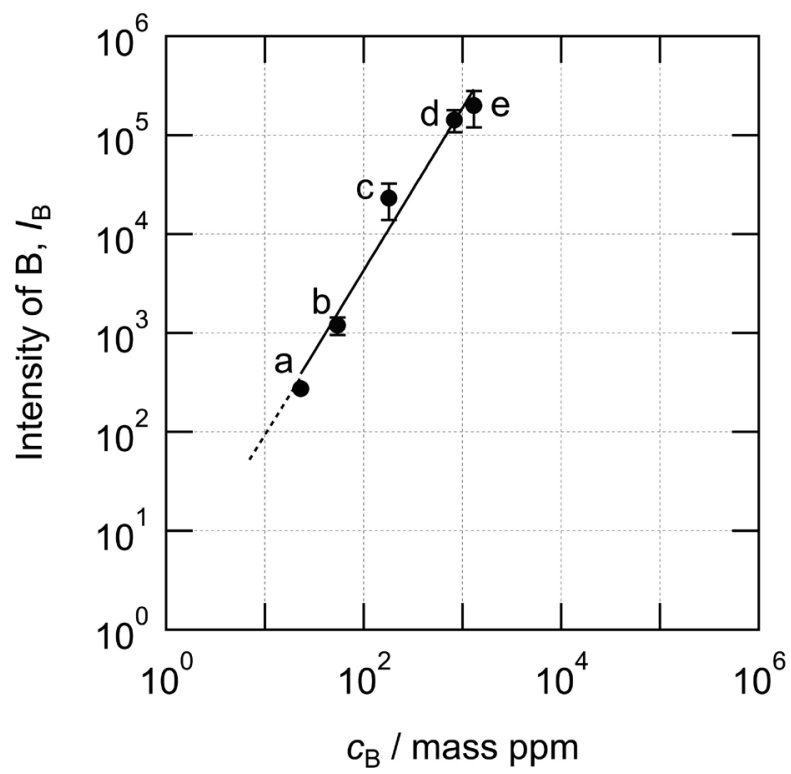

Fig. 3. Relationship between the intensity, $I_{\mathrm{B}}$ and the concentration, $c_{\mathrm{B}}$ of $\mathrm{B}$ in some alloy samples. The concentration of B (in mass ppm) is 23 for a, 54 for b, 180 for c, 824 for d, and 1300 for e. Error bars indicate the standard deviation of averaged values measured from several regions.
文献によれば， $\alpha$ 鉄中のBの固溶限濃度は $900{ }^{\circ} \mathrm{C}$ で 5 〜 20 mass ppm, $800{ }^{\circ} \mathrm{C}$ で $4 \sim 8$ mass ppm, $700{ }^{\circ} \mathrm{C}$ で 2 3 mass ppm である ${ }^{3,18)}$ 。Fig.3の両対数グラフにおける校正線 の傾きは 1 からずれており, $c_{\mathrm{B}}$ と $I_{\mathrm{B}}$ は線形関係にない。 $I_{\mathrm{B}}$ の 常用対数 $\log I_{\mathrm{B}}$ を, $c_{\mathrm{B}}$ の常用対数 $\log c_{\mathrm{B}}$ の $n$ 次関数 $(n=1.6)$ として近似すると, この校正線の外挿から, 10 mass ppmで の二次イオン強度は約 100 と見積もられる。したがって，こ の強度以下のプロファイルを解析し拡散係数を算出した。 Fig.4の強度プロファイルにはこの強度を基準強度として破 線で示す。また, $\log c_{\mathrm{B}}=0.60 \log I_{\mathrm{B}}+0.16$ の近似式から $I_{\mathrm{B}}$ を $c_{\mathrm{B}}$ に変換し, 濃度プロファイルを解析した。

\section{$3 \cdot 2$ 濃度プロファイル}

Fig.4に三つの温度で得られた Bの濃度分布を示す。分析 はメサ法に統一して行った。 ${ }^{56} \mathrm{Fe} と{ }^{27} \mathrm{Al}$ の二次イオン強度 も同時に測定した。なお, Bと一次イオンの $\mathrm{O}^{2+}$ が結合した BO イオンは質量数が $27 て ゙{ }^{27} \mathrm{Al}$ と等しい。それについては 後述する。

$700^{\circ} \mathrm{C}$ で $2.75 \mathrm{~h}$ 熱処理した試料 (a) のプロファイルでは, 表面から $50 \mathrm{~nm}$ までが $\mathrm{Al}_{2} \mathrm{O}_{3}$ 膜であるが，スパッタリング におけるミキシング効果により Bが検出されている。 Feの 強度は, $\mathrm{Al}_{2} \mathrm{O}_{3}$ 膜の界面で変化したのち, $50 \mathrm{~nm}$ 以降は $10^{5}$ 程度でほぼ一定に推移する。50-200 nmの範囲ではBの強 度が $5 \times 10^{4}$ の一定值で推移する。ここでの強度が $\mathrm{B}$ の拡散 源濃度に相当し，拡散熱処理の間は拡散源の濃度が保持さ れていたと考えられる。200 nmから $350 \mathrm{~nm}$ 付近まではや や急峻に直線的に，350 nmより内部では破線の基準強度よ り低い範囲で緩やかに濃度が低下する。200 nmから $350 \mathrm{~nm}$ 付近までの強度は破線の強度を上回り，二相分離の濃度に 相当する。熱力学的には二相分離した拡散層が生成するこ とは考えられない。拡散に伴う何らかのミクロ組織形成に 由来するものか, あるいはSIMSの分析上の理由なのか, 現時点では明らかではない。

$700^{\circ} \mathrm{C} \times 5.5 \mathrm{~h}$ および $700^{\circ} \mathrm{C} \times 11 \mathrm{~h}$ のプロファイルも（a) と同様であった。これらのプロファイルは, 誤差関数型の 解およびその近似式を当てはめて解析した。また，拡散対 実験で不純物の低濃度の極限における拡散係数を求める際 に用いられる Hallの方法による解析も行った (3・3・2 項)。

一方, $800{ }^{\circ} \mathrm{C} \times 5 \mathrm{~h}(\mathrm{~b})$ および $900^{\circ} \mathrm{C} \times 0.75 \mathrm{~h}(\mathrm{c})$ のプロ ファイルではB強度は表面近傍から $50 \mathrm{~nm}$ 付近にかけて急 激に下がっている。この部分は $\mathrm{B}$ の濃度分布ではなく, 検 出分解能に起因する変化とみなせる。同じ範囲で $\mathrm{A} 1$ の強度 は $10^{7}$ 程度で推移しており, $\mathrm{Al}_{2} \mathrm{O}_{3}$ 保護膜は残留している。 $50 \mathrm{~nm}$ より内部では, 破線の基準強度よりも低い範囲で $\mathrm{B}$ の濃度は緩やかに低下している。この場合はBが拡散侵入 するとともに拡散源の濃度が低下したと考えられる。この 場合の境界条件に対応する拡散方程式の薄膜問題の解 (ガ ウス分布型) を用いて解析した $(3 \cdot 3 \cdot 1$ 項)。

Fig. 5 に $800^{\circ} \mathrm{C} \times 5 \mathrm{~h}$ (黒) と拡散前のプロファイル (青) 
を重ねて示す。これらのデータを得た試料はそれぞれ別の 試料個体だが, $\mathrm{Fe}-\mathrm{B}$ 層および $\mathrm{Al}_{2} \mathrm{O}_{3}$ 層の堆積を同時に行っ たものである。 $\mathrm{Fe}$ の強度は両者とも同等の強度で推移して いる。表面での ${ }^{27} \mathrm{~A} 1$ の強度はほぼ等しい。拡散前の ${ }^{27} \mathrm{~A} 1$ の

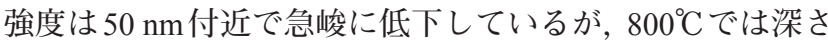
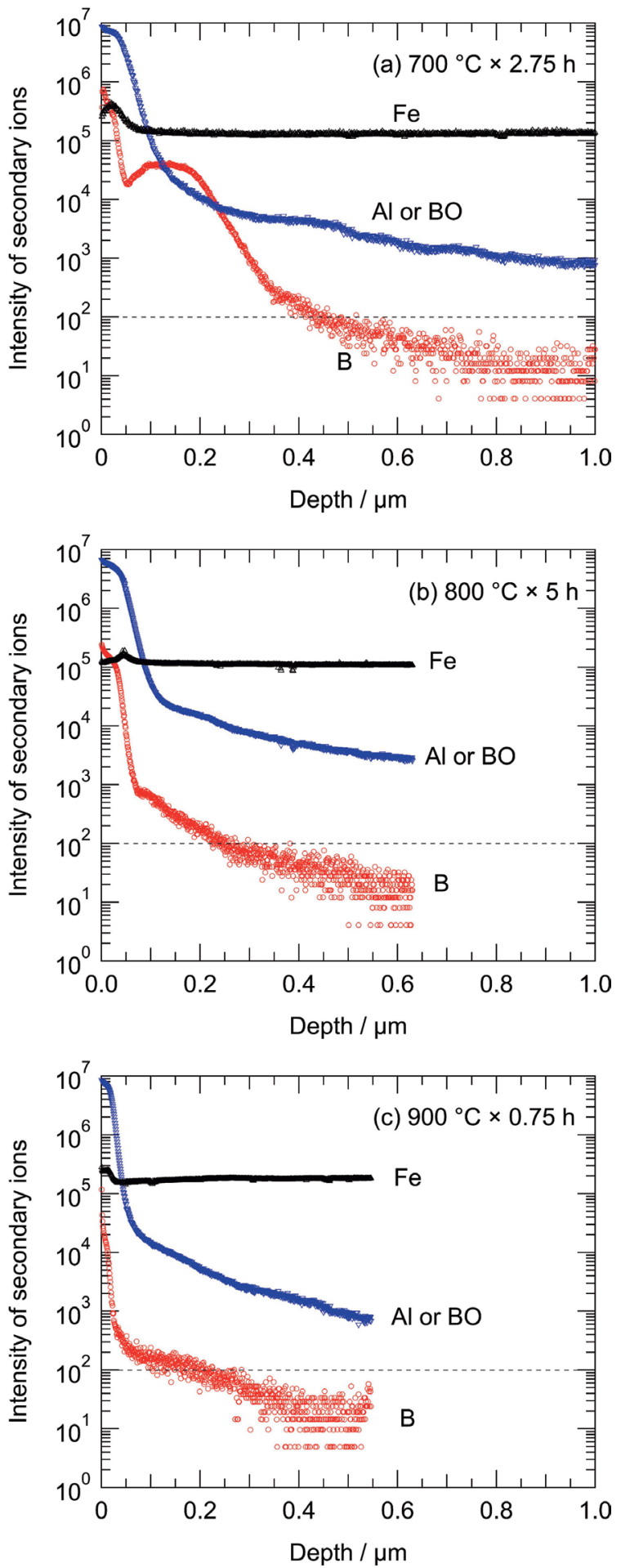

Fig. 4. Typical intensity profiles in the samples diffusionannealed at (a) $700^{\circ} \mathrm{C}$ for $2.75 \mathrm{~h}$, (b) $800^{\circ} \mathrm{C}$ for $5 \mathrm{~h}$, and (c) $900^{\circ} \mathrm{C}$ for $0.75 \mathrm{~h}$. The horizontal dashed line indicates the intensity level expected for 10 mass ppm B. (Online version in color.)
分布が若干ぼやけている。Fe-B層が堆積している拡散前の 試料のBの強度は $100 \mathrm{~nm}$ 付近まで $5 \times 10^{3}$ 程度となってい るが，一定ではない。いくつかの測定でこのような測定結 果が得られたが，原因は不明である。B強度は $100 \mathrm{~nm}$ 付近 の界面で急峻に低下し, バックグラウンドレベルの強度に 落ち着く。一方, $800^{\circ} \mathrm{C}$ の試料内部に扎ける $\mathrm{B}$ 強度はバック グラウンドレベルよりは十分に高い強度で緩やかに低下し ている。これは拡散によって生じた濃度分布と見なせる。

\section{$3 \cdot 3$ 拡散係数の算出}

$3 \cdot 3 \cdot 1$ 拡散源濃度が保たれていない場合

表面に堆積された濃度 $c_{0}$, 厚さ $d$ の拡散源から溶質が媒 質中に拡散する場合, 時間 $t$ における媒質中の濃度分布は 次のガウス型関数で表される。

$$
c(x, t)=\frac{c_{0} d}{\sqrt{\pi D t}} \exp \left(-\frac{x^{2}}{4 D t}\right)
$$

ここで, 溶質の拡散係数 $D$ は, 濃度分布が式 (1) に従えば, 距離 $x$ の 2 乗に対して $\mathrm{B}$ 濃度 $c_{\mathrm{B}}$ の対数をプロットして得ら れる直線の傾きから求められる。 $800^{\circ} \mathrm{C} \times 5 \mathrm{~h}$ 打よび $900^{\circ} \mathrm{C}$ $\times 0.75 \mathrm{~h}$ におけるその関係をFig.6に示す。罒中の実線は固 溶限濃度以下での傾きであり，これから拡散係数 $D$ を求め た。得られた $D$ の值は，以下の $3 \cdot 3 \cdot 2$ 項での解析結果も 含めてすべて Table 1 に示す。

Fig.4 (b) および4 (c) のプロファイルでは, 質量数27の イオン強度は $\mathrm{B}$ と似た変化を示している。この濃度分布を 同様にして解析すると, Table 1 に示したBの拡散係数と 同等の值が得られた。仮に $\mathrm{Al}_{2} \mathrm{O}_{3}$ 層から解離した $\mathrm{Al}$ が $\mathrm{Fe}$ 中に拡散したとすれば $\mathrm{Fe}$ 中の $\mathrm{Al}$ の拡散係数に近い值とな

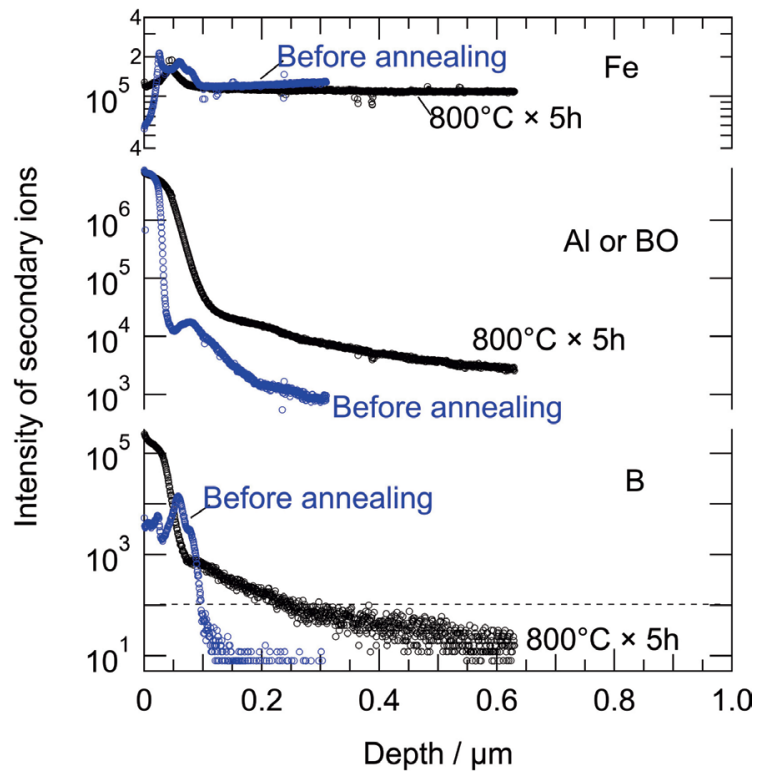

Fig. 5. Comparison of concentration profiles before (in blue) and after (in black) annealing at $800^{\circ} \mathrm{C}$ for $5 \mathrm{~h}$. The upper frame is for $\mathrm{Fe}$, the middle for $\mathrm{Al}$ or $\mathrm{BO}$, and the lower for B. (Online version in color.) 
るはずであるが, $\mathrm{Al}$ の拡散係数は $800^{\circ} \mathrm{C} \sim 900^{\circ} \mathrm{C}$ で $10^{-16}$ $10^{-15} \mathrm{~m}^{2} \mathrm{~s}^{-1}$ の大きさであり ${ }^{20,21)}$, 得られた值はこれより 3 桁 小さい。したがって, Fe内部における質量数27のイオン強 度の分布はBOに由来するものと考えられる。

\section{$3 \cdot 3 \cdot 2$ 拡散源濃度が保たれている場合}

表面の溶質濃度 $c_{\mathrm{s}}$ が一定に保持された条件の下で，溶質 原子が媒質中に拡散する場合，拡散係数が濃度に依存しな ければ, 濃度分布は次の誤差関数型となる。

$$
c(x, t)=c_{\mathrm{s}}\left[1-\operatorname{erf}\left(\frac{x}{2 \sqrt{D t}}\right)\right]
$$

Fig.4（a）に示した実験では，拡散熱処理の間に拡散源濃度 が一定に保たれており，誤差関数型の解に対応する境界条 件となっていたとみなせる。Fig.4 (a) における Fe-B 薄膜と
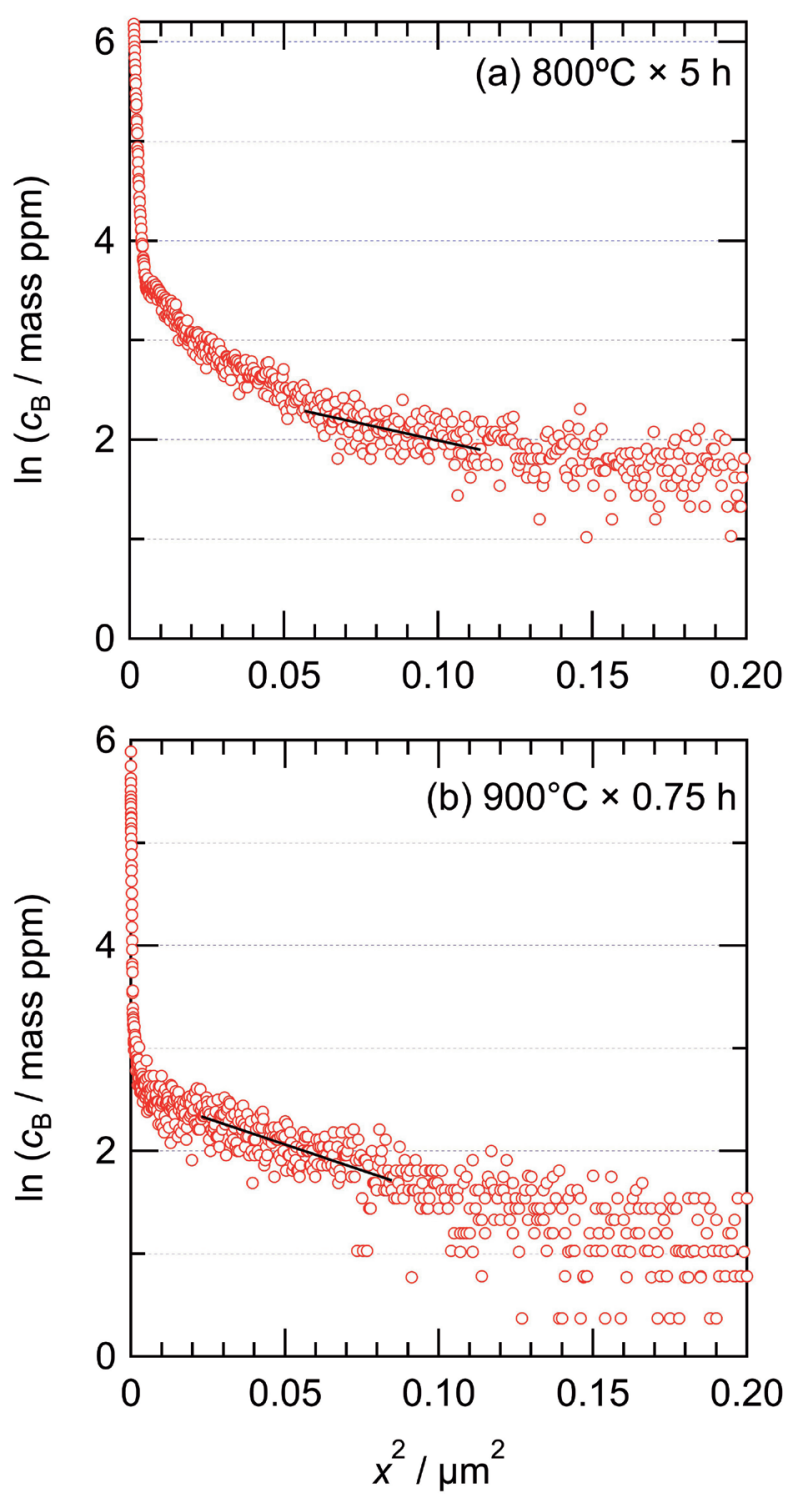

Fig. 6. Concentration profile of $\mathrm{B}$ in the samples annealed at (a) $800^{\circ} \mathrm{C}$ for $5 \mathrm{~h}$ and (b) $900^{\circ} \mathrm{C}$ for $0.75 \mathrm{~h}$ converted from Figs.4 (b) and (c), respectively, according to eq.(1). (Online version in color.)
純鉄の元の界面位置から内部の全範囲に対して式 (2) を適 用したものがFig.7 (a) である。 $\alpha$ 固溶体でのBの拡散係数 を決定するには, 固溶限以下の濃度域でフィッティング関 数が実験プロファイルと一致することが望まれるが, Fig.7 (a)のように一致はよくない。そこで, 誤差関数の級数展 開による近似式を用いて解析を行った。誤差関数は erf $(z)$ は，引数 $z \gg 1$ のとき

$$
\operatorname{erf}(z) \simeq 1-\frac{1}{z \sqrt{\pi}} e^{-z^{2}}
$$

と近似できる。ここから，

$$
\ln \{z[1-\operatorname{erf}(z)]\}=\ln \left(\frac{1}{\sqrt{\pi}}\right)-z^{2}
$$

が得られる。ここで $z=x /(4 D t)^{1 / 2}$ とし, 1-erf $(z)$ が元のプ ロファイルの $c(x) / c_{\mathrm{s}}$ であるから，それに距離 $x$ をかけてそ の対数を縦軸にとり，距離 $x$ の 2 乗に対してプロットする。 濃度分布が式 (4) に従えば直線関係になる。Fig.7（b) はそ の関係を示したものである。このグラフで，固溶限以下の $\mathrm{B}$ 濃度に相当する $0.28 \leq x^{2} / \mu \mathrm{m}^{2} \leq 0.55$ の範囲の傾きから $D$ を 求めた。

$\alpha$ 固溶体中のBの拡散係数を得るには，上のように固溶 限以下の低濃度領域の分布を解析して求めるのが適当で ある。拡散対実験で溶質原子の低濃度の極限における拡散 係数を求めるのにHallの方法 (またはHall-Crankの方法 ${ }^{19)}$ ) がある。Hallの方法では, 縦軸に濃度の逆誤差関数の值

$$
u=\operatorname{erf}^{-1}\left(\frac{2 c}{c_{\infty}}-1\right)
$$

$\left(c_{\infty}\right.$ は拡散源の濃度 $)$ を, 横軸 $\eta\left(=x /(4 t)^{1 / 2}\right)$ に対してプ ロットし，直線的になる領域の傾き $h$ と切片 $k$ を決める。係 数 $h, k$ と拡散係数 $D$ の関係式

\begin{tabular}{|c|c|c|c|}
\hline \multicolumn{2}{|c|}{ Diffusion annealing } & \multirow{2}{*}{$\begin{array}{l}\text { Method of } \\
\text { analysis }\end{array}$} & \multirow{2}{*}{$D / \mathrm{m}^{2} \mathrm{~s}^{-1}$} \\
\hline Temperature $/{ }^{\circ} \mathrm{C}$ & Time / h & & \\
\hline \multirow{6}{*}{700} & \multirow{2}{*}{2.75} & Error function & $(2.3 \pm 0.2) \times 10^{-17}$ \\
\hline & & Hall-Crank & $(1.0 \pm 0.5) \times 10^{-17}$ \\
\hline & \multirow{2}{*}{5.5} & Error function & $(3.8 \pm 0.7) \times 10^{-18}$ \\
\hline & & Hall-Crank & $(2.5 \pm 0.4) \times 10^{-18}$ \\
\hline & \multirow{2}{*}{11} & Error function & $(4.6 \pm 2.2) \times 10^{-18}$ \\
\hline & & Hall-Crank & $(3.4 \pm 1.2) \times 10^{-18}$ \\
\hline \multirow{2}{*}{800} & 2.75 & Thin-film solution & $(5.0 \pm 0.6) \times 10^{-18}$ \\
\hline & 5 & Thin-film solution & $(3.0 \pm 0.4) \times 10^{-18}$ \\
\hline \multirow{2}{*}{900} & 0.75 & Thin-film solution & $(9.2 \pm 0.7) \times 10^{-18}$ \\
\hline & 1.5 & Thin-film solution & $(7.0 \pm 0.9) \times 10^{-18}$ \\
\hline
\end{tabular}

Table 1. Diffusion coefficient of $\mathrm{B}$ in $\alpha$-Iron obtained by analyzing the concentration profiles by various methods. 


$$
D(c)=\frac{1}{h^{2}}+k \frac{\sqrt{\pi}}{h^{2}}(1+\operatorname{erf} u) \exp \left(u^{2}\right) \cdots
$$

から, Dが得られる。この解析を Fig. 8 に示す。極低濃度領 域では $u$ と $\eta$ は直線的な関係にあり, $D$ が濃度に依存せず に一定となっている。

Table 1 に示すように, 誤差関数型の近似解と Hallの方法 を適用して求めた $700^{\circ} \mathrm{C} の D$ は打打む一致する。ただし, $700^{\circ} \mathrm{C}$ の拡散係数は $800^{\circ} \mathrm{C}$ およ゙ $900^{\circ} \mathrm{C}$ の值と同等か上回っ ている。3・2で述べたように $700^{\circ} \mathrm{C}$ のプロファイルには 説明がつかない点があり，実験および解析の両面で再検討 の余地がある。

\section{$3 \cdot 4$ 拡散係数の温度依存性}

得られた Bの拡散係数の值を文献值とともにFig.9に示 す。Fig.9にはTable 1のデータ点をすべてプロットした。前 述のように $700^{\circ} \mathrm{C}$ の測定および解析には再検討の余地があ
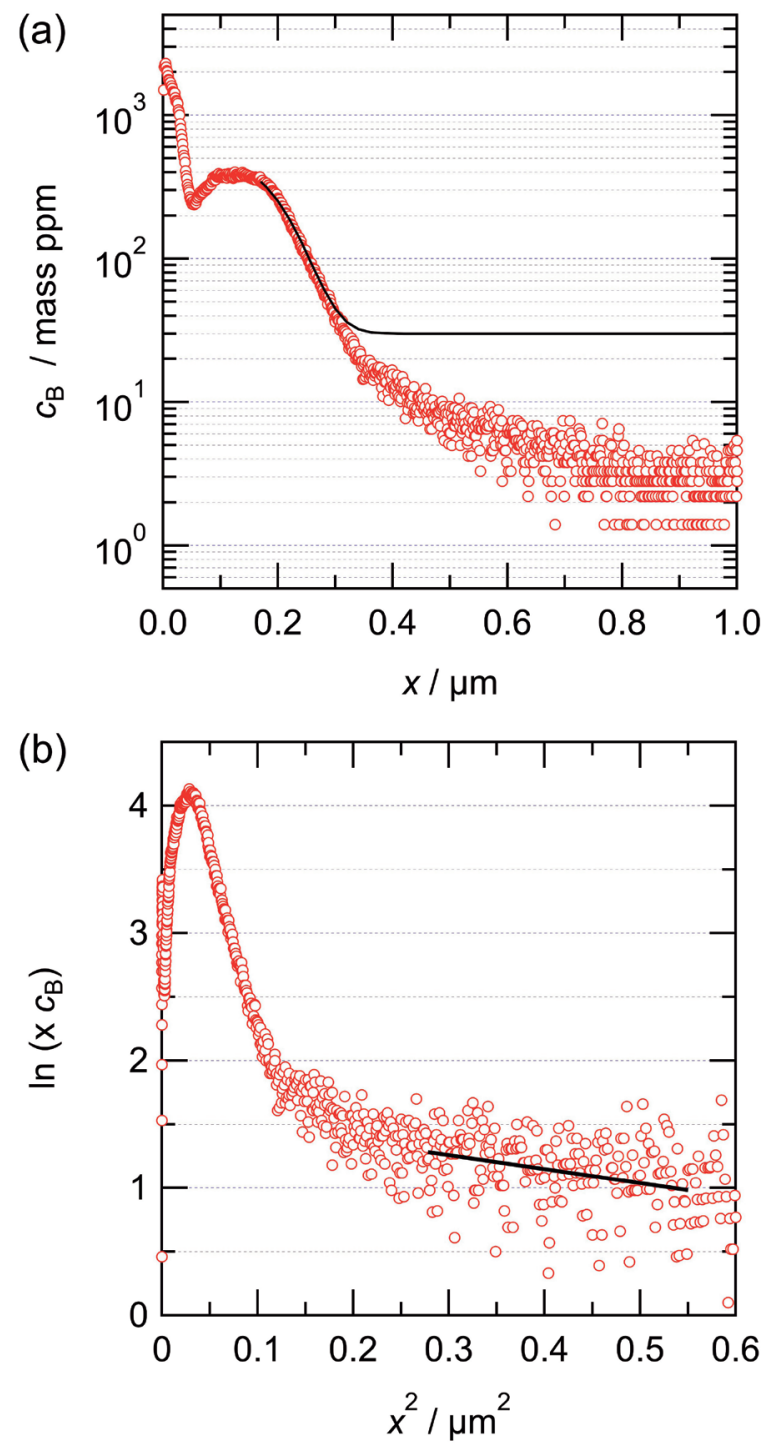

Fig. 7. Concentration profile of $B$ in the sample annealed at $700^{\circ} \mathrm{C}$ for $2.75 \mathrm{~h}$ according to (a) eq.(2) and (b) its approximate solution, eq.(4). (Online version in color.)
り，また，三つの温度のデータ点はアレニゥス則に従うよ うには見えない。本研究で得られた拡散係数の值は $700^{\circ} \mathrm{C}$ から $900^{\circ} \mathrm{C}$ の温度範囲で $10^{-18} \mathrm{~m}^{2} \mathrm{~s}^{-1}$ のオーダーである。長 距離拡散の実験により同様の温度域で測定されたBusby $ら^{4,5)}$ と Wang $ら^{8)}$ の拡散係数の值と比べると $7 \sim 8$ 桁小さ い。

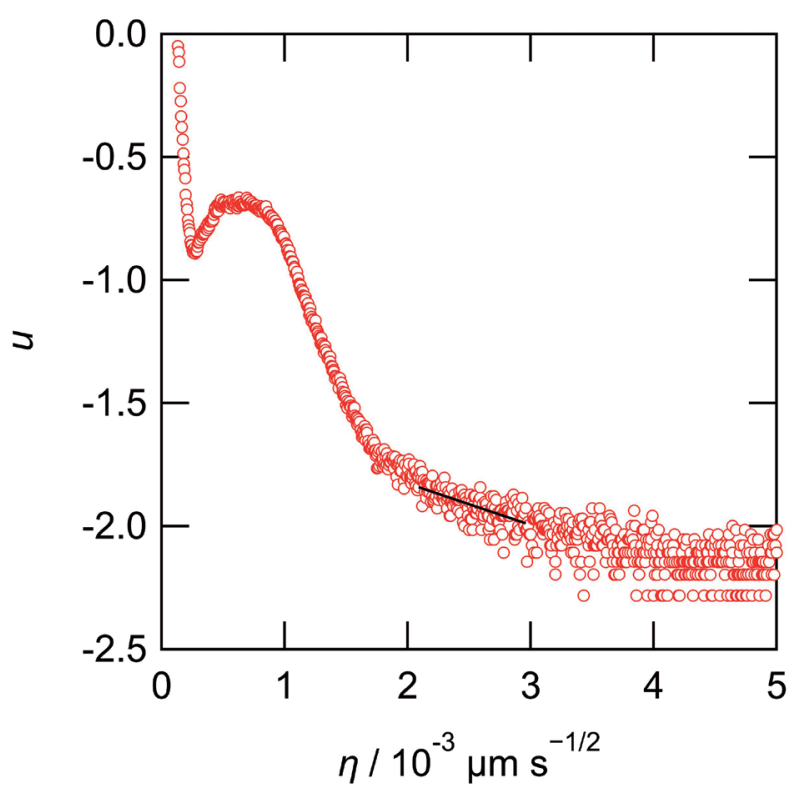

Fig. 8. Concentration profile of $\mathrm{B}$ in the sample annealed at $700^{\circ} \mathrm{C}$ for $2.75 \mathrm{~h}$ according to eqs.(5) and (6) for Hall's method of analysis. (Online version in color.)

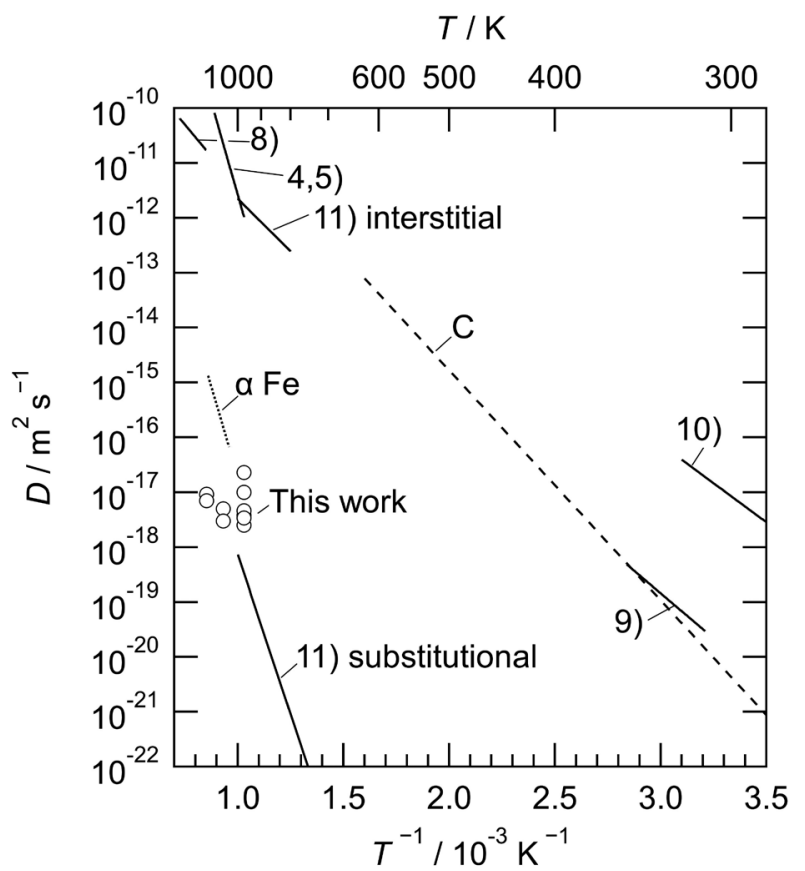

Fig. 9. Temperature dependence of the diffusion coefficient of B in $\alpha$ Iron: open circles show the data obtained by this study and solid lines the literature data with tags of reference numbers. The self-diffusion coefficient of iron (dotted line) and the diffusion coefficient of $\mathrm{C}$ (dashed line) in $\alpha$ Iron are shown together for comparison. 
$\alpha$ 鉄中の Bの固溶位置の決定は, $\mathrm{X}$ 線回折法 ${ }^{22}$ やイオン チャネリング法 ${ }^{23)} に よ り$ 試みられている。X線回折法で は, 格子定数の測定結果から置換型固溶が示唆されている が，イオンチャネリングの実験では明確な結論には至って いない。Fors and Wahnström ${ }^{11)}$ は理論計算により Bの固溶形 態として侵入型よりも置換型が安定であることを示し, 空 孔機構による拡散の活性化エネルギーと振動数因子を計算 した。本研究で得られた拡散係数はその計算結果に近い。 すなわち， $\alpha$ 鉄中のBは高温では置換型に固溶し，空孔を 介して拡散することが示唆される。

Fors and Wahnströmの計算によれば, 定圧下でのBの侵 入型八面体位置と置換型位置への溶解エネルギーの差は $+0.06 \mathrm{eV}$ と小さい。すなわち, 侵入型八面体位置への固溶 も無視はできず, 熱空孔濃度が低い温度域では C P N と同 様に侵入型機構で拡散する可能性もある。その場合, CP $\mathrm{N}$ と同程度の大きさのスヌーク緩和ピークが検出される可 能性がある ${ }^{24)}$ 。ただし，先行の Thomas and Leak ${ }^{9)}$ と Hayashi and Sugeo ${ }^{10)}$ の試料にはCやNが 40〜90 at. ppm含まれてお り,これらの緩和ピークが明瞭に観測されている。つまり, B 単独の緩和ピークと見なすには慎重になるべきだろう。 したがって, $\mathrm{C}$ と $\mathrm{N}$ を極力除去した $\mathrm{Fe}-\mathrm{B}$ 希薄固溶体試料を 準備して力学緩和の実験を行い，スヌーク緩和を検証する ことが望まれる。

\section{4. 結言}

結晶粒を粗大にした純鉄に $\mathrm{Fe}-\mathrm{B}$ 薄膜を堆積し, $700^{\circ} \mathrm{C}$, $800^{\circ} \mathrm{C}$ および $900^{\circ} \mathrm{C} て ゙ \mathrm{~B}$ を拡散させた。その長距離拡散プロ ファイルを二次イオン質量分析法により測定し，いくつか の解析解を適用して拡散係数を求めた。得られた知見は以 下の通りである

（1）拡散焼鈍前のBの二次イオン強度は, Fe-B 薄膜／純鉄 界面で急峻に低下しバックグラウンドレベルの強度 となった。一方，拡散焼鈍後のBの二次イオン強度は， Fe-B薄膜／純鉄界面から深さ $0.6 \sim 1 \mu \mathrm{m}$ に渡り,バッ クグラウンドレベルよりも 1 桁高いレベルで緩やかに 低下した。すなわち，Bの拡散による濃度分布が観測 された。

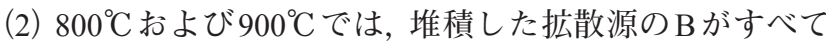
内部に浸透する形態のプロファイルが得られた。一方, $700^{\circ} \mathrm{C}$ では，拡散源が表面に残留する形態となった。前 者には, 薄膜解を, 後者には誤差関数型の解打よび希 薄濃度における解析に適用される Hallの方法を適用 して解析を行った。得られた拡散係数の值は $700^{\circ} \mathrm{C}$ か ら $900^{\circ} \mathrm{C}$ の温度範囲で $10^{-18} \mathrm{~m}^{2} \mathrm{~s}^{-1}$ のオーダーであった。 長距離拡散の実験により同様の温度域で測定された Busby らと Wang らの拡散係数の值に比べると 7〜8桁 小さく，置換型の機構を仮定したForsらの理論計算值
に近い。

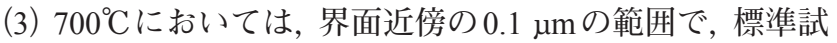
料から見積もられた固溶限濃度の強度より高いレベル の濃度分布が観測された。これは相平衡の観点からは 理解できず, 実験および解析の両面で再検討の余地が ある。

\section{謝辞}

本研究は科学研究費基盤研究 (B)（26289231）の支援の もとで実施された。SIMS の利用にあたり「物質・デバイス 領域共同研究拠点」の共同研究プログラムの助成を受けた。 研究の遂行にあたっては，日本鉄鋼協会「鉄鋼中の軽元素 と材料組織打よび特性」研究会 (2016年3月～2019年3月) に打いての議論が助けとなった。東北大学の関戸信彰博士 (物質・材料研究機構, 現東北大学) には, 種々の濃度の標 準試料を提供いただき，さらに実験方法について有用な意 見をいただいた。ここに記して謝意を表す。

\section{文献}

1 ) C.R.Simcoe, A.R.Elsea and G.K.Manning: J. Met., 7(1955), 193.

2 ) M.Ueno and K.Itoh: Tetsu-to-Hagané, 74(1988), 1073 (in Japanese).

3 ) T.B.Cameron and J.E.Morral: Metall. Trans. A, 17(1986), 1481.

4 ) P.E.Busby, M.E.Warga and C.Wells: J. Met., 5(1953), 1463.

5 ) P.E.Busby and C.Wells: J. Met., 6(1954), 972.

6 ) Y.Iijima, K.Kimura and K.Hirano: Acta Metall., 36(1988), 2811

7 ) J.Ågren: Scr. Metall., 20(1986), 1507.

8 ) W.Wang, S.Zhang and X.He: Acta Metall. Mater., 43(1995), 1693.

9 ) W.R.Thomas and G.M.Leak: Nature, 176(1955), 29.

10) Y.Hayashi and T.Sugeno: Acta Metall., 18(1970), 693

11) D.H.R.Fors and G.Wahnström: Phys. Rev. B, 77(2008), 132102.

12) S.Frank, U.Södervall and C.Herzig: Intermetallics, 5(1997) 221

13) S.V.Divinski, F.Hisker, T.Wilger, M.Friesel and C.Herzig: Intermetallics, 16(2008), 148.

14) T.Taoka, T.Takeuchi and S.Takeuchi: Tetsu-to-Hagané, 52(1966), 187 (in Japanese).

15) H.E.Rosinger, W.J.Bratina and G.B.Craig: J. Cryst. Growth, 7(1970), 42.

16) R.von Criegern, I.Weitzel and J.Fortner: Secondary Ion Mass Spectrometry, SIMS IV, ed. by A.Benninghoven, J.Okano, R.Shimizu and H.W.Werner, Springer, Berlin, (1984), 308.

17) J.M.McKinley, B.B.Rossie, M.A.Decker and F.A.Stevie: Microsc. Microanal., 8(2002), 542

18) H.Ohtani, M.Hasebe, K.Ishida and T.Nishizawa: Trans. Iron Steel Inst. Jpn., 28(1988), 1043.

19) J.Crank: The Mathematics of Diffusion, Oxford University Press, Oxford, (1975), 230.

20) I.A.Akimova, V.M.Mironov and A.V.Pokoyev: Phys. Met. Metallogr., 56(1983), 175

21) K.Nishida, T.Yamamoto and T.Nagata: J. Jpn Inst. Met., 34(1970), 591 (in Japanese).

22) P.M.Strocchi, B.A.Melandri and A.Tamba: Nuovo Cimento B, 51(1967), 1 .

23) J.U.Andersen, E.Lægsgaard and L.C.Feldman: Radiat. Eff., 12(1972), 219.

24) M.Souissi, Y.Chen, M.H.F.Sluiter and H.Numakura: Comput. Mater. Sci., 124(2016), 249. 